\title{
The Implementation of the Quantum Teaching Strategy with Multiple Intelligence Approach at State Senior High School
}

\author{
Basuki Tri Harnoto ${ }^{1}$, Rahyu Setiani ${ }^{2}$, B Widuroyekti ${ }^{3}$, Dwi Sambada ${ }^{4},{ }^{*}$ Dwikoranto $^{5}$, \\ Lindsay N. Bergsma ${ }^{6}$
}

1SMAN 1 Krembung Sidoarjo, Indonesia

2Bhinneka PGRI University of Tulungagung, Indonesia

3,4Universitas Terbuka, UPBJJ-UT Semarang, Indonesia

${ }^{*}$ Department of Physics, Universitas Negeri Surabaya, Indonesia

${ }^{6}$ Tilburg School of Social and Behavioral Sciences, Tilburg University, The Netherlands

\begin{tabular}{|c|c|}
\hline 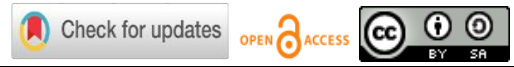 & DOI: https://doi.org/10.46245/ijorer.v2i1.78 \\
\hline Sections Info & ABSTRACT \\
\hline Article & e student learning outcome \\
\hline er 28,2020 & out in \\
\hline Final Revised: January 03, 2021 & 4 stages: planning, action and observation, reflection, and revision that \\
\hline & rvation, \\
\hline ry 31,2021 & ticipants of this research are \\
\hline Keywords: & class XI-3 students of State Senior High School 1 Krembung. Data were \\
\hline Act & tively quantitative. Observation cycle 1 , motivation by the \\
\hline Lear & objectives, explanation of working on worksheets, \\
\hline Multiple intelligence & worksheet systematics, class control, seating settings, and intelligence use \\
\hline Quant & $\begin{array}{l}\text { are lacking. The mean obtained is } 55 \text { with grade completeness of } 38 \% \text {. } \\
\text { Observation cycle } 2 \text {, delivery of learning objectives hastily, connecting }\end{array}$ \\
\hline 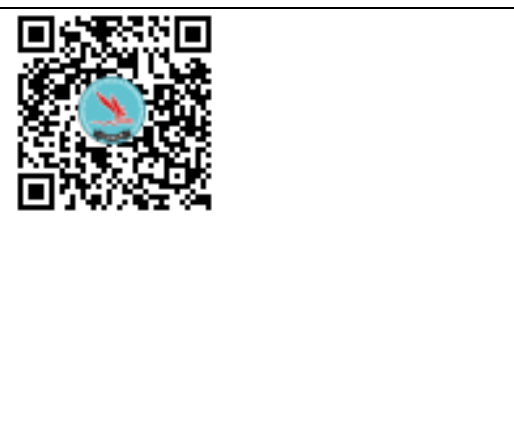 & $\begin{array}{l}\text { material with daily phenomena is less clear, concluding that the material is } \\
\text { not systematic. However, many students begin to maximize their } \\
\text { intelligence to obtain a mean } 63.75 \text { with class completeness of } 60 \% \text {. } \\
\text { Observation cycle } 3 \text { shows an improvement, and the process runs smoothly } \\
\text { so that the mean is } 74 \text { with grade completeness } 81 \% \text {. Students' positive } \\
\text { activity increased from cycle I to cycle III while learning achievement from } \\
\text { cycle one to cycle three increased respectively by } 38 \%, 60 \% \text {, and } 81 \% \text {. The } \\
\text { student's response questionnaire showed that students had a positive } \\
\text { attitude with } 81.73 \% \text { and } 18.27 \% \text { negative. In conclusion, student } \\
\text { achievement and activity in learning had increased and received a positive } \\
\text { response. }\end{array}$ \\
\hline
\end{tabular}

\section{INTRODUCTION}

Based on the preliminary observations, some problems occurred in class XI-3 at State Senior High School 1 Krembung, Sidoarjo. The average daily test score of 55.7 and classical learning completeness of $48.57 \%$ with details of 14 students completing learning and 18 students who did not complete a minimum completeness criteria limit of 70. Teachers tend to use one intelligence to measure student learning success, namely logical-mathematical intelligence in student learning activities and student learning tests. Some students experienced difficulties solving physics problems. This problem is due to the solving of physics questions only through a mathematical approach, meaning that only logical-mathematical students can understand physics well (Suryani, 2016; Saputra, 2014), even though not all students have the adequate logical intelligence-mathematically. 
The Implementation of the Quantum Teaching Strategy with Multiple Intelligence Approach at State High School

Students are more involved with logic-mathematical or computational problems with a high level of difficulty. There is difficulty in realizing the use of methods where students expected to be more active and more critical in responding to the lessons they learn (Acat, 2014; Prastyo, 2012). There is a tendency for teachers to measure student achievement with only one intelligence, that is logical-mathematical intelligence. However, students have potential, character, uniqueness in increasing learning success, and teachers' difficulty changing class conditions to be more active, especially for students. If the teacher forms groups then give the counting questions in groups, one of the students relies on other students who have relatively good logical-mathematical intelligence in completing the task (Isnaini et al., 2016; Rachmawati, 2012). There is still a lack of attention to the interests of students who have their way of achieving learning success with the intelligence possessed by a student that must be optimized, namely intelligence: Linguistic intelligence, musical intelligence, logical-mathematical intelligence, visual-spatial intelligence, bodily-kinesthetic intelligence, interpersonal intelligence, intrapersonal intelligence (Gardner, 2013; Guzman, 2010; Said \& Budimanjaya, 2015).

Intelligence as the ability to solve problems, or create valuable products in one or several cultural environments or societies must be empowered primarily in education. Not all students have the same interests and abilities, and not all of us learn the same way (Munawaroh, 2011; Widjajanti, 2012; Yaumi \& Nurdin, 2013). Based on the statement above, students have different intelligence tendencies and have different ways of solving education problems. Through the empowerment of multiple intelligence, it is a that multiple intelligence can accommodate students with unique, different mindsets in achieving a specific goal and can increase student enthusiasm in learning (Astuti, 2018; Aka, 2016). For this reason, an approach with multiple intelligence in learning is necessary so students can participate in increasing their learning success, develop and strengthen student intelligence and facilities and infrastructure that facilitate have an active role in achieving learning goals (Anaduaka, 2011). Learning through a multiple intelligence approach will be more accomodating for its success if teachers have motivation and creativity in changing the learning experience, as well as the courage to step out of the comfort zone in teaching and teacher's plan (Calik \& Birgill, 2013; Al-Zyoud \& Nemrawi, 2015). To get out of the comfort zone, by trying more variety, innovative and creative learning, this can be done in an integrated way in quantum teaching, namely "Bring Their World to Our World and Deliver Our World to Their World" (DePorter et al., 2013; Lasimin, 2013). One way to do it is by linking (daily) life events, thoughts, or feelings related to its subjects. Teachers need to understand and know their interests and aspirations and thoughts linked to the learning experiences itself. Teachers will find it easier to guide students, to prepare them to enter the world of learning. The teacher provides a more profound understanding of education by relating to an event, thought, or feeling in everyday life with subjects. Ultimately, the teacher provides more in-depth knowledge to students to learn what they get in full. It can apply in life other than conceptual understanding (Khashan, 2014).

Quantum learning requires teachers to change the classroom's learning atmosphere to be more active, dynamic, and lively with all its components that interact with each other in synergy to achieve the learning goals. By facilitating students accordingly, 
The Implementation of the Quantum Teaching Strategy with Multiple Intelligence Approach at State High School

having positive outcomes are expected. Facilitating students are done through modalities that are reserved and provide students' diversity and provide freedom of learning within agreed boundaries to foster motivation, interest, and attention from students in receiving knowledge in student learning achievement (DePorter et al., 2013; Manurung, 2013). Quantum Teaching is the same as a symphony in which there are elements to create a learning environment, as explained above, these elements are context and content. Context is an atmosphere of change (orchestra) by empowering a solid foundation, a supportive environment, and a dynamic learning design. The content elements include excellent presentation, flexible facilitation, learning skills for learning, and life skills (Gardner, 2013; Suardana, 2013).

The orchestration of success through the context described above will create a sense of belonging. The sense of belonging will increase and result in appreciation so that the class will become a learning community that students strive for and keen on doing. Hence, it is not because of impulsiveness that will impact themselves negatively. The explanation of the context itself is orchestrating several things, that are: (a) Orchestrating the atmosphere, (b) Orchestrating the Platform, (c) Orchestrating the Environment, (c) Orchestrating the Teaching Design (DePorter et al., 2013; Gardner, 2013). The objectives of this study are: (1) Describe the use of multiple intelligence approaches with the Quantum Teaching strategy in improving student learning achievement, (2) Describe student responses, and (3) Describe the increase in teacher activity and student enthusiasm during learning.

\section{RESEARCH METHOD}

\section{Types of research}

This type of research is classroom action research. Classroom action research is used to improve learning in the classroom by as many as three cycles. Each cycle consists of planning, carrying out activities, and observations, then reflecting by producing revisions to the next planning. It will be seen that the increase in student learning achievement, besides observing teacher activities and students, learning outcomes, and student responses. Classroom action research is research carried out collectively by social groups, including education aiming to improve their work quality and overcome various pressing problems (Sugiyono, 2015).

\section{Research Subjects}

The subjects to be researched were class XI-3 at State Senior High School 1 Krembung, Sidoarjo. This research was conducted by the State Senior High School 1 Krembung.

\section{Description of Cycle in Classroom Action Research Planning}

This stage is the preparation stage in learning used in teaching and learning activities. This planning includes intelligence diagnosis sheets, making syllabi, compiling Learning Improvement Plans, preparing Student Activity Sheets and Student Evaluation Sheets, Assessment Sheets, learning observation sheets, teacher activity observation sheets and student activities, student response sheet.

\section{Action and observation}


The Implementation of the Quantum Teaching Strategy with Multiple Intelligence Approach at State High School

When implementing the action, the researcher carried out the Learning Improvement Plan activities that carry out learning activities by applying multiple intelligence methods in the Quantum Teaching strategy. At this stage, there is also an action to take a student's intelligence diagnosis, which is expected to determine the tendency of students' intelligence. Observations are made simultaneously with the implementation of the action using observation sheets. Observations are aimed at teachers and students when teaching and learning activities take place.

\section{Reflecting}

Reflection is done by reviewing the plans that have been made, actions that take place, and the results of observations made. By reflecting, information about deficiencies in a cycle and improvements to the next cycle's planning are made according to the evaluation results.

\section{Revise}

This stage is carried out by making or formulating corrective steps based on the results of the reflections that have been made. The results of these improvements are manifested in planning in the next cycle. If it meets the minimum criteria specified, the cycle is terminated.

\section{Data Collection Instruments}

The instrument used consists of: (1) a list of intelligence diagnoses, containing statements that have been categorized according to the types of intelligence themselves. (2) Observation sheet of teacher activities and student activities. Observers fill out this observation sheet with attention to student activities during the learning process in student intelligence assessment sheets. (3) Learning Outcomes Test, given before students receive the subject matter and then the final test carried out after teaching and learning activities occur. (4) Student response questionnaire sheet.

\section{Instrument and Data Analysis Techniques Intelligence Test Data Analysis}

Before learning instruments are made, intelligence tests are needed to determine the dominant intelligence students possessed in the class being studied. The results of which are used as an illustration to determine the appropriate learning method in designing or designing learning that applies multiple intelligence, as for the analysis carried out on This intelligence test data uses the following formula:

$$
\text { percentageof intelligence score }=\frac{\sum \text { score of each intelligence }}{\sum \text { maximum intelligence score }} x 100 \%
$$

(Sugiyono, 2015)

Each intelligence score is obtained from the number of questions on each intelligence in the multiple intelligence diagnosis lists according to the student's nature and character. The maximum intelligence score is the total score of all intelligence obtained. 


\section{Observational Data Analysis}

The observations' results are intended to describe implementing teaching and learning activities during research on teacher and student activities using the multiple intelligence approach.

Student activity data during the learning process

Student activity data is calculated as a percentage (\%) of each indicator with the following formula:

$$
\% \text { Activity of Student }=\frac{\sum \text { frequency indicator thatappears }}{\sum \text { overallindicat or frequency }} \times 100 \%
$$

The indicator with the highest percentage shows the dominant student activity.

\section{Teacher activity data in managing learning}

Teacher activities' data is obtained from the learning management observation data used to analyze teachers' ability to manage learning by calculating the average of each aspect of 3 meetings. Then the average value is converted to the following criteria:

$$
\begin{aligned}
& 0.00-0.69=\text { Less } \\
& 1.70-2.59=\text { Average } \\
& 2.60-3.49=\text { Good } \\
& 3.50-4.00=\text { Very good }
\end{aligned}
$$

(Arikunto, 2011)

Additionally, the results of observations of teacher activity are analyzed using the following formula:

$$
\% \text { Activity of teacher }=\frac{\sum \text { frekwenscy indicatorthatappeas }}{\sum \text { overallfrekwency indicator }} \times 100 \%
$$

\section{Student response data}

Student response data were analyzed by counting each question answer as a percentage (\%):

$$
\% \text { Student Response }=\frac{\sum \text { respondent's answer }}{\sum \text { respondent }} \times 100 \%
$$

Assessment criteria:

- $20 \%-55 \%=$ Negative

- $56 \%-75 \%=$ Neutral

- $76 \%-100 \%$ = Positive

\section{The percentage of completeness calculation}

In order to check if students completed the questionnaires, the following formula is used:

$$
\text { individual completenos }: \frac{\text { thenumber of correctanswers }}{\text { thetotalnumber of questions }} \times 100 \%
$$

(Noor, 2011) 
The Implementation of the Quantum Teaching Strategy with Multiple Intelligence Approach at State High School

With the minimum completeness criteria in school is 72 .

$$
\text { percentage completeness }=\frac{\sum \text { students who complete }}{\sum \text { theentirestudent }} X 100 \%
$$

(Noor, 2011)

Class average value

$$
\text { averagescore }=\frac{\text { totalstudent scores }}{\text { totalstudent }}
$$

(Arikunto, 2011)

\section{RESULTS AND DISCUSSION \\ Initial Diagnostic Results}

The results of the initial diagnosis of intelligence were obtained after students answered the Preliminary Diagnosis Test results. The results of the calculation of the diagnostic test can be seen in Table 1 .

Table 1 Intelligence diagnostic results.

\begin{tabular}{clc}
\hline Numb. & \multicolumn{1}{c}{ Intelligence Diagnostic Test Statement Indicator } & Class Score (\%) \\
\hline 1 & $\begin{array}{l}\text { Linguistic: likes to read books, easy to tell stories, has good } \\
\text { vocabulary skills. }\end{array}$ & 13.45 \\
2 & $\begin{array}{l}\text { Logical-Mathematic: more able to solve calculation } \\
\text { problems than reasoning, to calculate accurately. }\end{array}$ & 12.21 \\
3 & $\begin{array}{l}\text { Kinesthetic: always wants to move when sitting for long, } \\
\text { likes to do lab work. }\end{array}$ & 12.83 \\
4 & $\begin{array}{l}\text { Visual: likes to scribble on books with pictures, likes to } \\
\text { read books with lots of pictures rather than reading } \\
\text { textbooks. }\end{array}$ & 15.36 \\
& $\begin{array}{l}\text { Interpersonal: have many friends, like to make friends \& } \\
\text { work together in groups. } \\
\text { Musical: sensitive to rhythm, easy to catch the music. } \\
\text { Intrapersonal: can concentrate well, high awareness of } \\
\text { themselves, likes to work alone, has high self-esteem, } \\
\text { independent, can motivate oneself. }\end{array}$ & 17.93 \\
\end{tabular}

Based on Table 1, when viewing the score as a whole, it varies greatly. Linguistic intelligence is $13.45 \%$, logical-mathematical intelligence is $12.21 \%$, kinesthetic intelligence is $12.83 \%$, visual intelligence is $15.36 \%$, and interpersonal intelligence is $17.93 \%$. Music intelligence is $12.83 \%$ and intrapersonal intelligence $13.76 \%$. These percentages explain that the seven intelligence of students varies from one student to another. With this being said, the teacher's ability is required to manage the class and make its teaching plan; therefore, students will understand and comprehend physics material well (Hoerr et al., 2010 ). The teacher's plan is made in such a way as to the intelligence that students have so that learning feels fun for students; consequently, individual student intelligence data is needed (Kartikasari, 2016; Huda, 2013).

Nevertheless, this data cannot be used as a final result to determine the student's intelligence. This data can be used as an initial diagnosis to determine the tendency of students' intelligence. Upon further inspection, the more dominant intelligence is 
The Implementation of the Quantum Teaching Strategy with Multiple Intelligence Approach at State High School

Interpersonal intelligence at $17.93 \%$, and the least is logical-mathematical intelligence, which is $12.21 \%$. Based on this analysis, the seventh intelligence that is in line with physics lessons is linguistic, logical-mathematical, visual, kinesthetic and intrapersonal intelligence. Thus, the researcher uses this five intelligence in learning, especially in teaching design in student activity sheets, while musical and intrapersonal intelligence does not. Used in design but can be applied in a class at certain times as a refreshing class (Chatib, 2013).

This difference in intelligence level shows that students have certain intellectual tendencies and can solve problems, particularly those related to education. That does not mean that other intelligence types are missing or absent, but intelligence is not well developed yet. Less developed intelligence can be improved by continuously being trained because by having the same intelligence that dominates these students, they can become superior students. Therefore, researchers created learning instruments in ways that five intelligence can be applied in teaching and learning activities besides training other intelligence that is still unsubstantial with the hope of developing well, which ultimately impacts student achievement (Lunenburg \& Lunnenburg, 2014).

\section{Results and Discussion Cycle I to Cycle III} Student Activities Towards Types of Intelligence

Table 2. Activities on student intelligence.

\begin{tabular}{|c|c|c|c|c|}
\hline \multirow{2}{*}{ Numb. } & \multirow{2}{*}{ Intelligence } & \multicolumn{3}{|c|}{ Result in $(\%)$} \\
\hline & & Cycle 1 & Cycle 2 & Cycle 3 \\
\hline 1 & Linguistic & 72 & 81 & 90 \\
\hline 2 & Logical-mathematic & 59 & 64 & 73 \\
\hline 3 & Visual & 62 & 67 & 79 \\
\hline 4 & Kinesthetic & 65 & 77 & 84 \\
\hline 5 & Interpersonal & 63 & 80 & 84 \\
\hline
\end{tabular}

On Table 2, cycle I to cycle III shows student activities or enthusiasm based on the student intelligence assessment sheet. The student intelligence assessment sheet was obtained through students' worksheets using either dominant or not intelligence shows an increase from cycle to cycle which means students use intelligence is dominant well and trains to develop less dominant intelligence (Abdulkarim \& Al Jadiry, 2012). It is hoped that in the future students can use and train their intelligence in learning and in real life to solve problems (Al-Zyoud \& Nemrawi, 2015; Alice et al., 2020).

\section{Student Intelligence Ability Against Student Achievement}

Table 3 Learning outcomes based on intelligence.

\begin{tabular}{clrcc}
\hline Numb. & & \multicolumn{3}{c}{ Result in (\%) } \\
\cline { 3 - 5 } & & Cycle 1 & Cycle 2 & Cycle 3 \\
\cline { 3 - 5 } 1 & Linguistic & 58.7 & 60.0 & 72.5 \\
2 & Logical-Mathematic & 55.0 & 68.7 & 77.5 \\
3 & Visual & 53.7 & 65.0 & 73.8 \\
4 & Kinesthetic & 56.3 & 61.8 & 72.5 \\
\hline
\end{tabular}


The Implementation of the Quantum Teaching Strategy with Multiple Intelligence Approach at State High School

From Table 3, it can be seen that student learning achievement in cycle I for students in the linguistic intelligence category as a percentage of $58.7 \%$, students with logicalmathematical intelligence are $60 \%$, students with visual intelligence are $65 \%$, students with kinesthetic intelligence are $56 \%, 3 \%$. In contrast, in cycle II linguistic intelligence, student learning achievement rose to $60 \%$, which means the smallest increase in learning achievement was $1.3 \%$ and in logical-mathematical intelligence increased significantly, namely $68.7 \%$, which means an increase in learning achievement for this intelligence. This is very large because students can solve more complex problems in working on questions (Lunnenburg \& Lunnenburg, 2014) while visual intelligence has increased by $65 \%$, which means that the increase is relatively $11.3 \%$, so students with this intelligence can work on past questions. For students with kinesthetic intelligence has a percentage of $61.8 \%$, meaningful $\mathrm{Ti}$ students are capable enough to solve problems (Irdes, 2014; Adhitama, 2015). Whereas in cycle III for students with dominant linguistic, logical-mathematical, kinesthetic intelligence, respectively, had a learning achievement percentage of $72.5 \%, 77.5 \%, 72.5 \%$, the three intelligence had the same average increase; significantly $12 \%$. This average means that students with the three intelligence can solve the problems well, and students with dominant intelligence in visuals. This increase is not far from other intelligence, namely $73.8 \%$ with an increasing percentage of $9 \%$. So in the third cycle, students can achieve good learning achievement (Astuti, 2018; Calik \& Birgill, 2013).

\section{Learning Management By Teachers In Using Multiple Intelligence Approaches With Quantum Teaching Strategies}

The results obtained based on Cycle I to Cycle III data can be seen in Table 4 .

Table 4. Learning management.

\begin{tabular}{|c|c|c|c|}
\hline \multirow{2}{*}{ Numb. } & \multirow{2}{*}{ Cycle } & \multicolumn{2}{|c|}{ Learning Management } \\
\hline & & Achievement & Information \\
\hline 1 & Cycle 1 & 54.5 & Enough \\
\hline 2 & Cycle 2 & 72.0 & Good \\
\hline 3 & Cycle 3 & 83.0 & Very good \\
\hline
\end{tabular}

Table 4 shows that the management of learning from cycle I to cycle III has increased in the succession of $54.5 \%, 72 \%, 83 \%$. This result indicates that the increase in activity and student learning achievement is related to teachers' success (Hoerr, 2016; Lasimin, 2013; Suryani, 2016; Bancong, 2013).

\section{Student Achievement After Multiple Intelligence Approach with Quantum Teaching Strategy is Applied}

The data obtained is based on students' average score in each cycle and the process of students who have achieved completeness in learning in each cycle. The formative test data analysis results from cycles I, II, III, can be seen in Table 5 below. 
The Implementation of the Quantum Teaching Strategy with Multiple Intelligence Approach at State High School

Table 5. Classification of learning achievement.

\begin{tabular}{clccc}
\hline Numb. & \multicolumn{1}{c}{ Description } & Cycle 1 & Cycle 2 & Cycle 3 \\
\hline 1 & The number of students & 32 & 32 & 32 \\
2 & Average value & 55 & 63.75 & 74 \\
3 & The number of students who completed & 12 & 19 & 26 \\
4 & The number of students is not complete & 20 & 13 & 6 \\
5 & Completeness Percentage & 38 & 60 & 81 \\
\hline
\end{tabular}

Table 5 shows the percentage increase in the class average from the formative test, from cycle 1 to cycle II. The increase is $16 \%$ and from cycle II to cycle III an increase of $10.25 \%$. The analysis above shows that the average class score is getting better and increasing besides that learning completeness is also increasing (Prabawanti, 2015; Mohiddin, 2015; Alice et al., 2020; Cahyaningrum, 2019). The minimum grade completeness criteria are 72.

\section{Student Response Questionnaire}

Student response analysis is obtained from a questionnaire where the questionnaire is a sheet that must be filled in and used to determine the level of object response to teaching and learning activities in class. The questionnaire in this study was given to all XI-MIPA3 classes who had participated in the teaching and learning process. The questionnaire given by the students covered six aspects of assessment, namely: whether the teacher taught, whether the instrument was understandable or not, helping understanding or not by applying multiple intelligence learning with the quantum teaching strategy, whether the students were interested in learning if the researcher was doing was reused in learning other materials, whether or not physics lessons are engaging after using multiple intelligence learning with quantum teaching strategy, whether learning uses multiple intelligence with quantum teaching strategy (Sudarman, 2016; Siregar, 2014).

Student interest in teachers' teaching methods was $87.5 \%$, clarity of the Student Activity Sheet received responses of $68.7 \%$, and understanding of the material using multiple intelligence with a quantum teaching strategy was $78.1 \%$. The multiple intelligence's approvals with a quantum teaching strategy were carried out with different materials' response was $81.2 \%$. Additionally, the percentage of students' interest in physics after using multiple intelligence with the quantum teaching strategy was $84.3 \%$. Following this result, the students' enjoyment in learning using multiple intelligence with the quantum teaching strategy was $90.6 \%$. From this data, it turns out that the lowest response percentage is about the clarity of the Student Activity Sheet that has been studied. The percentage is obtained because four intelligence questions include four intelligence because they are faced with questions that lead to one intelligence. Such as logical-mathematical intelligence; however, it is still categorized as a positive response because it is still above 65\% (Lile, 2014; Sari, 2013). In conclusion, students can have an active interest and enthusiasm in physics using the quantum teaching strategy's multiple intelligence approach. Which means that students' responses to learning using the multiple intelligence approach with the quantum teaching strategy are responded positively (Lunenburg \& Lunenburg, 2014). 
The Implementation of the Quantum Teaching Strategy with Multiple Intelligence Approach at State High School

\section{CONCLUSIONS}

The application of the multiple intelligence approach with the quantum teaching strategy can improve student achievement. Based on the quantitative analysis results, the teacher's learning management skills increased from Cycle 1 to 3, namely $64.5 \%$ in Cycle 1, 72\% in Cycle 2 and 83\% in Cycle 3 and student activities the use of student intelligence. Also increased from cycle I to cycle III. Students have high activity/ enthusiasm for physics after using learning by applying the multiple intelligence approach with the quantum teaching strategy, which means that their response to learning is positive. Along with the research results and the results of the data obtained and the conclusions above, suggestions can be made in this study, including similar research, improvements should be made to obtain better results. The research will be better if the teacher explains how to meet the quantum teaching strategy, namely more modern facilities and infrastructure, especially in ICT. For further research, it is recommended first to apply each intelligence in one meeting to monitor intelligence abilities students to solve problems and monitor each student's intelligence development.

\section{REFERENCES}

Abdulkarim, R., \& Al Jadiry, A. (2012). The effect of using cooperative learning and multiple intelligences theory on physical concepts acquisition. British Journal of Arts and Social Sciences, 10(2), 137-152.

Acat, M. B. (2014). An investigation the effect of quantum learning approach on primary school 7th grade students' sciences achievement, retention and attitude. Educational Research Association the International Journal of Research in Teacher Education, 5(2), 11-23.

Adhitama, N., Parmin, \& Sudarmin. (2015). Implementasi quantum learning berbantu mind mapping worksheet untuk mengukur kemampuan komunikasi dan hasil belajar peserta didik. Unnes Science Education Journal, 4(3), 1022-1030.

Aka. (2016). Model quantum teaching dengan pendekatan cooperative learning untuk meningkatkan kualitas pembelajaran PKN. Jurnal Pedagogia, 5(1), 5-9.

Alice, Y. V. W., Okvin, E. K., \& Mardince, S. (2020). Efektivitas penggunaan model quantum teaching dalam meningkatkan hasil belajar IPA. Journal of Education Technology, 4(2), 96-102

Al-Zyoud, N. F., \& Nemrawi, Z. M. (2015). The efficiency of multiple intelligence theory (MIT) in developing the academic achievement and academic-self of students with mathematical learning disabilities in the areas of addition, subtraction, and multiplication. American International Journal of Social Science, 4(2), 171-180.

Anaduaka, U. S. (2011). Multiple intelligences teaching method and mathematics teaching. JORIND, 9, 116-123.

Arikunto, S. (2011). Dasar-dasar evaluasi pendidikan. Jakarta: Bumi Aksara.

Astuti, T. P., Masykur, R., \& Pratiwi, D. D. (2018). Pengaruh model pembelajaran tandur terhadap kemampuan pemahaman konsep dan penalaran matematis peserta didik. Jurnal Pendidikan Matematika FKIP Univ. Muhammadiyah Metro, 7(2), 201-209.

Bancong, Safitri, H. dan Husain. (2013) Pengaruh pendekatan multiple intelligences melalui model pembelajaran langsung terhadap sikap dan hasil belajar kimia 
The Implementation of the Quantum Teaching Strategy with Multiple Intelligence Approach at State High School

peserta didik di SMA Negeri 1 Tellu Limpoe", Jurnal Pendidikan IPA Indonesia, 2 (2), 156-160

Cahyaningrum, A. D., Yahya, \& Asyhari, A. (2019). Pengaruh model pembelajaran quantum teaching tipe tandur terhadap hasil belajar. Indonesian Journal of Science and Mathematics Education, 2(3), 372-379.

Calik, B., \& Birgill, B. (2013). Multiple intelligence theory for gifted education: Criticism and implications. Journal for the Education of the Young Scientist and Giftedness, 1(2), $1-12$.

Chatib, M. (2013). Sekolahnya manusia: Sekolah berbasis multiple intelligences di Indonesia. Bandung: Penerbit Kaifa.

DePorter, Bobbi, \& Hernacki, M. (2013). Quantum learning: Membiasakan belajar nyaman dan menyenangkan. Bandung: Kaifa Learning.

Gardner, H. (2013). Multiple intelligences, kecerdasan majemuk teori dalam praktik. Tangerang Selatan: Interaksara.

Guzman, M.R. (2010). Multiple intelligences and the level of performance grade V Pupils in DMMMU-ELS: Basis for modifying teaching strategies and assessment tools. E-International Scientific Research Journal, 48(5), 49-53.

Hoerr, T. R., Boggeman, S., \& Wallach, C. (2010). Celebrating every learner: Activities and strategies for creating a multiple intelligences classroom. San Fransisco: Jossey-Bass.

Huda, K.M. (2013). Penerapan model quantum teaching dan seqip untuk meningkatkan aktivitas dan hasil belajar IPA. Jurnal Pendidikan, (01:06):09.

Irdes, I. (2014). Pengaruh model pembelajaran quantum teaching terhadap hasil belajar siswa pada materi pokok zat dan wujudnya di kelas vii semester 1 SMP Negeri 3 Percut Sei Tuan. Jurnal Inpafi, 2(2), 91-99.

Isnaini, M., Wigati, I., \& Halimatussya'diyah. (2016). Pengaruh model pembelajaran quantum teaching dengan langkah-langkah tandur terhadap keterampilan proses belajar siswa materi sel Kelas XI di SMA Muhammadiyah 1 Palembang. Jurnal Bioilmi, 2(1), 16-29.

Kartikasari, A. (2016). Pengembangan perangkat pembelajaran matematika SMA kelas $x$ pada materi trigonometri dan geometri dengan pendekatan problem-based learning berbasis multiple intelligences gardner berorientasi pada prestasi, kemampuan koneksi matematis, dan self-esteem siswa. Tesis. PPs-UNY.

Khashan, K. H. (2014). Conceptual and procedural knowledge of rational numbers for riyadh elementary school teachers. Journal of Education and Human Development, 3(4), 181-197.

Lasimin. (2013). Penerapan metode quantum teaching pada pembelajaran pkn untuk meningkatkan hasil belajar siswa kelas IV SD negeri 053984 hinai kanan. Langkat: Badan Penerbit Unimed.

Lile, R. (2014). The assessment of learning outcomes. Procedia-Social and Behavioral Sciences, 163, 125-131.

Lunenburg, F. C., \& Lunenburg, M. R. (2014). Examining the effects of multiple intelligence instruction of math performance. International Journal of Scholarly Academic Intellectual Diversity, 16(1), 1-14.

Manurung, N. (2013). Pemanfaatan multiple intelegence dalam proses pembelajaran. Jurnal Keguruan, 1(1), 49-56. 
The Implementation of the Quantum Teaching Strategy with Multiple Intelligence Approach at State High School

Mohiddin, D. P. (2016). Pengaruh model pembelajaran quantum teaching dan kemampuan berpikir matematis terhadap hasil belajar siswa. Jurnal Technopreneur (JTECH), 4(2), 90-93.

Munawarah, I. (2011). Pengembangan Rencana pelaksanaan pembelajaran berbasis multiple intelligences. Yogyakarta: FIP UNY.

Noor, J.. (2011). Metodologi penelitian: Skripsi, tesis, disertasi, dan karya ilmiah. Jakarta: Kencana.

Prabawanti, E. S. (2015). Penerapan model pembelajaran quantum teaching dengan metode diskusi berbantuan lembar kerja siswa (LKS) untuk meningkatkan hasil belajar materi bentuk pangkat dan akar pada siswa kelas X. 6 semester I SMA Negeri 2 Magetan tahun pelajaran 2013/2014. Jurnal Ilmiah Pendidikan Matematika, 3(2), 390-397.

Prastyo, B. dan Fatah, A. (2012) Implementasi strategi pembelajaran quantum learning untuk meningkatkan minat dan hasil belajar dalam pembelajaran dasar otomotif pada siswa kelas $\mathrm{x}$ program keahlian teknih mekanik otomotif SMK Ma'arif ALMUNAwwir. Jurnal Pendidikan, 3(2), 1-21.

Rachmawati, R. (2012). The implementation quantum teaching method of graduate through up-grade hard skill and soft skill. Procedia-Social and Behaviour Sciences, 57(2), 477-487.

Said, A., \& Budimanjaya, A. (2015). 95 strategi mengajar multiple intelligences. Mengajar sesuai kerja otak dan gaya belajar siswa. Jakarta: Penerbit PrenadaMedia Group.

Saputra, R. (2014). Pengaruh model pembelajaran kuantum berseteng lingkungan sekolah terhadap hasil belajar ilmu pengetahuan alam (IPA) siswa tunanetra SMPLB-A YPAB Surabaya. Jurnal Pendidikan Khusus, 3(12), 5-6.

Sari, Y. K., Susilowati, S. M. E., \& Ridlo, S. (2013). Efektivitas penerapan metode quantum teaching pada pendekatan jelajah alam sekitar (JAS) berbasis karakter dan konservasi. Journal of Biology Education, 2(2), 96-105

Siregar, I. H., \& Juliani, R. (2014). Pengaruh model pembelajaran quantum teaching terhadap hasil belajar siswa pada materi pokok zat dan wujudnya di kelas VII semester I SMP negeri 3 Percut Sei Tuan T.P 2013/2014. INPAFI (Inovasi Pembelajaran Fisika), 2(2), 107-116.

Suardana, G., Wiarta, \& Sujana, W. (2013). Hubungan Antara Interpersonal Intelligence dan Motivasi Belajar Dengan Hasil Belajar IPA Siswa Kelas V SDN Gugus Letkol I Gusti Ngurah Rai Denpasar. Jurnal Mimbar PGSD. 2(1):9.

Sudarman, S. W., \& Vahlia, I. (2016). Efektifitas Penggunaan Metode Pembelajaran Quantum Learning terhadap Kemampuan Pemahaman Konsep Matematis Mahasiswa. Al-Jabar: Jurnal Pendidikan Matematika, 7(2), 275- 282.

Sugiyono. (2015). Metode Penelitian Pendidikan, Pendekatan Kuantitatif, Kualitatif, dan R \& $D$. Bandung: Alfabeta.

Suryani R. (2016). Pengembangan Perangkat Pembelajaran Matematika dengan Pendekatan Realistic Mathematics Education (RME) Berbasis Teori Multiple Intelligences Howard Gardner, Berorientasi pada Prestasi dan Kemandirian Belajar Siswa Kelas VIII SMP. Skripsi. FMIPA UNY.

Widjajanti, D. B. (2012). Teori kecerdasan majemuk: Apa dan bagaimana mengaplikasikannya dalam pembelajaran matematika. Diakses dari seminar.uny.ac.id pada tanggal 23 Mei 2019, Jam 23.44 WIB. 
The Implementation of the Quantum Teaching Strategy with Multiple Intelligence Approach at State High School

Yaumi, M., \& Nurdin, I. (2013). Pembelajaran berbasis kecerdasan jamak (multiple intelligences) mengidentifikasi dan mengembangkan multitalenta anak. Jakarta: Kencana Prenada media Group.

\section{Basuki Tri Harnoto}

SMAN 1 Krembung, Jalan Raya Kecamatan No. 2, Sidoarjo 61257, Jawa Timur, Indonesia

Email: triharnotobasuki8@gmail.com

\section{Rahyu Setiani}

Bhinneka PGRI University of Tulungagung,

Jl. Mayor Sujadi Timur No.7, Ploso Kandang, Tulungagung 66221, Jawa Timur, Indonesia

Email: $\underline{\text { rahyusetiani@gmail.com }}$

\section{B Widuroyekti}

UPBJJ-UT Semarang, Jl. Pantura Semarang-Kendal No.KM. 14, Mangkang Wetan,

Kec. Tugu, Kota Semarang 50154, Jawa Tengah, Indonesia

Universitas Terbuka, Indonesia

Email: barokaw@ecampus.ut.ac.id

\section{Dwi Sambada}

UPBJJ-UT Surabaya, Campus C Mulyorejo Unair 60115, Jawa Timur, Indonesia

Universitas Terbuka, Indonesia

Email: dwisambada@ecampus.ut.ac.id

\section{*Dwikoranto (Corresponding Author)}

Department of Physics, Faculty of Mathematics and Natural Science,

Universitas Negeri Surabaya,

Jl. Ketintang, Surabaya 60231, Jawa Timur, Indonesia

Email: dwikoranto@unesa.ac.id

\section{Lindsay N. Bergsma}

Psychology Student of Tilburg University

Tilburg School of Social and Behavioral Sciences (TSB)

Tilburg University, The Netherlands

Warandelaan 2, 5037 AB, Tilburg, The Netherlands

Email: u187576@uvt.nl | Lindsay.natalia@gmail.com 